\title{
PRIORITY OF THE PRIVATE LEGAL METHOD IN REGULATION OF IT RELATIONS IN THE CHANGING FORMS AND VECTORS OF THE IMPACT OF IT LAW
}

\section{Omelchuk O. S.}

\section{INTRODUCTION}

The field of IT law is developing rapidly in Ukraine and becoming one of the most promising areas of training for lawyers. The question of determining the place of IT law in the national legal system is extremely urgent. It is necessary to outline the boundaries and methods of legal regulation in this field, since the dynamics of development of relations in the field of information technology requires the widest possible expansion of the scope of information technology. The specificity of the information technology sector is marked by a tendency to self-regulate relations in this field, which is confirmed by the situation with crypto currency assets; relationships that arise during communication on social networks, etc.

However, most public relations, which are decisive for the sphere of interference with IT law, are regulated by state legal norms, but complicated by the informational features of their application. The process of formation of specific cross-sectorial features of legal regulation of relations in the field of IT is noted in the literature ${ }^{1}$.

The pluralism of views inherent in modern science opens new vectors of knowledge of law; it's not limited only as a social regulator. The application of the methodological tools of the various social sciences makes it possible to consider law in the context of its social nature, as an element of the social system.

Based on the civilizational approach, law is characterized as a phenomenon inherent in civilization, serving as an element of socio-political system and social consciousness, law is a component of the spiritual world of man and his worldview; law reflects the views of individuals and society as a whole about human status, truth and injustice, justice, good and evil, human rights abuses and restoration, crime and punishment, humanism and cruelty, etc ${ }^{2}$.

\footnotetext{
${ }^{1}$ Новицький А.M. Місце IT-права в загальній системі інформаційного права. URL: http://aphd.ua/publication-179/

2 Харитонов С.О. Сутність IT-права (IT- право як концепт). IT право: проблеми $i$ перспективи розвитку в Украӥні: збірник матеріалів науково-практичної конференції. Львів: НУ “Львівська політехніка”, 2016. С. 276.
} 


\section{General provisions on the consciousness and its types}

In order to determine the nature of the impact of IT law society and the dynamics of changing vectors of such influence, it is necessary to find out what information technologies at the current stage of development of science and technology influence the public consciousness.

Consciousness is the feeling of each person's existence and actions. It is a quality inherent in people that is a generalized and purposeful reflection of reality, imaginary construction of actions, predicting consequences, regulation and self-control of behavior, that has an external forms of creative expression and is language-related. Human consciousness is a reflection of information processes.

Social consciousness arises as a result of the dependence of human activity on social conditions of life, also is an implementation of the new type of orientation. That is, social consciousness is a product of social existence.

Over the course of history, a number of forms of social consciousness emerged and developed. There are morality, religion, philosophy, art, political consciousness and legal consciousness. Each of these forms has its own specificity and plays a special role in public life.

Social consciousness, together with the individual, makes, what is commonly called, the spirituality of the individual, society, nation, state, humanity. Social consciousness is the systematic unity of the sensual, informational and intellectual components that reflects all social being.

Individual and social consciousness constitute dialectical unity. Individual consciousness is formed and developed under the influence of social consciousness, and the social consciousness deepens its essence and replenishes its content at the expense of the individual. The carrier of social consciousness is society, the carrier of individual consciousness is the individual.

The public consciousness contains in itself the ideas, views, ideas, illusions, social feelings of people that are distributed in society. Public consciousness reflects the conditions of daily life, needs, interests.

It should be noted that any socially significant object of interest in society is reflected in the public consciousness. Information technology is no exception. By information technology we mean not only certain technological models and communication channels, but also the whole range of tools, mechanisms, techniques associated with the global expansion of the information space ${ }^{3}$.

${ }^{3}$ Стефанчук У. Інформаційні технології та їхній вплив на формування громадської думки в Україні. Украӥнська національна ідея: реалії та перспективи розвитку. 2008. Вип. 20. С. 130. 
Scientific progress that takes place in the process of self-realization of society, produce more and more ways and means of applying information, thus increasing its value. The increasing efficiency of the use of information assets, the information base of society is increasingly contributing to effective social development. The information space thus formed is attracting more and more subjects of different status - individual, society, state - each of which has its own interest.

The interests of the individual in the information field are to exercise human rights to access information and to use information for physical, spiritual, intellectual development and other activities.

Social consciousness is not a mathematical sum of the individuals of the members of the respective society; they are constantly interacting and developing in parallel, their development is determined by both common and individual factors for each form of consciousness.

The public interest does not always intersect with the individual, and therefore the public consciousness otherwise reflects the phenomenon of information technology. Today we are seeing a high-quality reincarnation of society based on information technology. At the present stage of civilization's development the processes of globalization, humanization, greening, and informatization are inherent in the public consciousness. Information technologies have a significant impact on such changes in the mass consciousness.

Modern information technologies have caused the emergence and intensive dissemination of fundamentally new models of social integration, communication, socio-political activity, lifestyle, education, etc. ${ }^{4}$

There are several factors behind the spread of information technology that have an impact on the public consciousness.

Dissemination of Internet resources with objective information on the implementation of various functions of the state, with various registers of legal information, monitoring studies of the efficiency of the work of the state apparatus and local self-government bodies - undoubtedly leads to the formation of public consciousness of the society of a fundamentally new type. Involvement of a large number of citizens in state processes through the mechanisms of direct democracy (electronic petitions, polls on official websites of state bodies, electronic appeals), widespread access to mathematical indicators that reflect the effectiveness of the activities of individual state or local governments, broad discussion of current and potential legislative initiatives - all these determine the functioning of modern civil society.

\footnotetext{
${ }^{4}$ Інформаційні технології як фактор суспільних перетворень в Україні : зб. аналіт. доп. / М. А. Ожеван, С. Л. Гнатюк, Т. О. Ісакова; за заг. ред. Д. В. Дубова. К. : НІСД, 2011. С. 3
} 
The active introduction of information technology in the economy also influences the formation of a new type of social consciousness. The widespread and relative availability of e-commerce technologies, the emergence of new technological models for doing business, consolidation of simple and clear rules of the legislation on the use of modern information technologies in business cause positive changes in the public consciousness, approaching the transition of society to the post-industrial model.

The spread of IT in the fields of education, science, culture is also reflected in the level of public consciousness, bringing the average member of society closer to the values of modern civilization and shaping the general intellectual level of society.

Information technology, however, can be dangerous for the individual and the public, if misused or malicious.

At the individual level, dangerous influences of the information space can lead to changes in the psyche, mental health of the person. We should talk about the degradation of personality, if the forms of reflection of reality are simplified, reactions are coarser and the transition from higher needs (in self-actualization, social recognition) to lower (physiological, everyday. There is also a shift in values, lifestyle, reference points, the worldview of the individual. Such changes cause antisocial actions and are dangerous for the whole society and the state ${ }^{5}$.

For example, the Internet at the present stage of development is a special virtual environment, which consists of virtually all those kinds of relationships that exist outside it, because the internet is a reflection of real life. The imaginary anonymity and unrestricted freedom of action on the Internet creates the illusion of permissiveness, which often translates into real-life behavior.

Information influence is also possible at the level of public consciousness. Negative influence is usually called manipulation of consciousness.

Awareness of the importance of the use of information technologies in everyday life and public life plays a paramount role in the development of the information society. Therefore, we can talk about the formation of information consciousness of society. As noted A.V. Kolodyuk, formation of information consciousness is a fundamental prerequisite for the use of information and communication technologies in the life of every citizen ${ }^{6}$.

\footnotetext{
5 Жарков Я. Небезпеки особистості в інформаційному просторі. Юридичний журнал. 2007. № 2. URL: http://www.justinian.com.ua/article.php?id=2554

${ }^{6}$ Колодюк А.В. Інформаційне суспільство: сучасний стан та перспективи розвитку в Україні: автореф. дис. на здобуття наук. ступеня канд. політ. наук. К., 2005. С. 10.
} 
The media consciousness according to the media can be divided into the following types:

1) information consciousness of the person, which reflects the attitude of the person to information technologies on a household level;

2) group information consciousness, which determines the understanding and use by a group of persons of a certain set of information knowledge;

3 ) information consciousness of society - provides a general understanding of the information sphere of society.

Public justice characterizes the attitude to the law of the whole society, reflects its interests.

The legal consciousness of a society is based on a historically defined system of social relations - economic, social, political, spiritual - throughout the whole society. It reflects the legal nature of relations in society, principles and patterns of legal communication between members of society, experience of legal activity ${ }^{7}$.

According to the level, form and volume of the reflection of legal life, social justice is divided into legal ideology and legal psychology. Legal ideology of society is a system of legal ideas, views, ideals, principles, concepts that are characteristic of the whole society. Legal ideology substantiates and evaluates existing or emerging legal relations, law and order. The best reflection of legal ideology is the system of legislation in the broad sense.

Legal psychology of society encompasses the totality of feelings, values, moods, desires, or experiences that are characteristic of the entire society.

Legal ideology should be formed as a process of revealing theoretical consciousness, coordinating and reconciling different public interests through the achievement of social compromise. In the development of legal ideology take part lawyers, political scientists, economists, take into account specifichistorical conditions of society life, balance of power, level of public consciousness, social psychology, will and interests of both majority and minority, other factors ${ }^{8}$.

Law influences society within its functions. The functions of law are the directions of its influence, which are inherent to it as a whole, and therefore inherent in each of its elements. A particular branch of law, given its specificity, may have additional special functions, may use some of the functions of law to a greater extent, and another may use less.

Legal influence on the public consciousness is exercised when performing (or not performing) by the right it social functions. Social functions are a

\footnotetext{
${ }^{7}$ Скакун О.Ф. Теорія держави і права : підручник. Х. : Консум, 2001. 656 с.

${ }^{8}$ Соснін О.В. Правова свідомість як фактор забезпечення засад захисту інформації. Захист інформації. 2010. № 1 (46). С. 10.
} 
specific perspective of law, where regulatory and protective functions are combined in a separate, qualitatively uniform sphere of social relations, economy, politics, ideology. Law performs a general social function of shaping legal values, principles and desirable behaviors.

In order for the law to really perform its functions, the subject must be clearly aware of its nature, goals, basis (through ideology and psychology) and put it into practice through appropriate actions (through the behavior of the subject of public relations). Under developed consciousness, in the result of this interaction happens a deep awareness and understanding of the role of law, it is evaluated in terms of criteria for compliance with the needs of society, awareness of the need for an acting system of legislation, compliance with the requirements of laws, etc. ${ }^{9}$

\section{The impact of IT law on the public consciousness}

The impact of IT law on the public consciousness means not only regulatory influence, but the whole spectrum of influence on the formation of new and change of old values, traditions and behaviors.

In order to determine the direction of the impact of IT law on the public consciousness, it is necessary to find out the sources of origin of law related to IT law. Among the traditional ways of IT law norms occurrence, related to the emergence of new socially significant relations and the subsequent creation of an effective regulator of such relations in the form of a rule, we note the emergence of a new method of lawmaking related to the globalization of relations (including European integration processes). for Ukraine).

In view of the obligations, that should be fulfilled by the Ukrainian legislator, certain norms are adopted, which are imposed by the international community and are implemented for reasons other than the sustainable evolutionary development of social relations.

In the legal literature exude three types of formation of legal rules in the field of IT:

- those that have happened historically (“About Information");

- those that have been accepted at the request of the international community (Law of Ukraine "On Electronic Digital Signature", "On Electronic Documents and Electronic Document Management";

- those adopted at the request of industry development (Law of Ukraine "On the National Informatization Program")

9 Бурдоносова М.А. Правовий нігілізм як форма деформації правової свідомості населення. Держава і право. Вип. 45. С. 57.

${ }^{10}$ Новицький A.M. Місце IT-права в загальній системі інформаційного права. URL: http://aphd.ua/publication-179/ 
We can trace the dependence of forms implementation of the rule of law and the level of interest in the immediate and effective implementation of the rule of law from the manner in which a separate legal rule arises, however, in the case of IT law, the above methods are generally acceptable.

The extraterritorial nature of the construction and operation of many IT objects necessitates a combination of national and international legal regimes for regulating them. A large number of IT relations are implemented through soft law in the form of various recommendations, resolutions and declarations issued by international organizations (International Telecommunication Union, World Intellectual Property Organization, UN, UNESCO, Council of Europe, Internet Corporation for Assigned Names and Numbers, etc. $)^{11}$.

All the features of the IT relationship listed above are also reflected in the nature of the impact of IT law on the public consciousness. The impact of the right on the public consciousness passes at two levels at once - the levels of perception of law and the levels of socio-legal actions (behavior). It is with these two levels that different directions of influence of law are connected.

Public relations that arise within the limits of the use of information technologies have a number of features, among them innovation, high technology, formality. The specificity of the sphere of relations, which is the subject of legal regulation of IT law, determines the peculiarities of the mechanism of influence of IT law on the public consciousness. Thus, within the information sphere of influence on the public consciousness, IT law forms an idea of the latest information technologies and reflects the attitude of the society (state) to certain elements of the information society.

Regulatory material in IT law can serve as a real source of education for society, which will serve as a key to attracting a wide range of subjects to IT relations and further development of information technologies. An important element of the mechanism of legal influence should be the stimulation by the state of the use of information technologies by people (electronic document circulation, filling in electronic declarations, online transactions, electronic citizens' appeals, etc.). Formation in the public consciousness of the positive image of "virtual" relationships, their security and perspective, accessibility and convenience - is the predominant goal of influence of IT law within the information direction of influence.

The value-oriented or axiological direction of the impact of IT law generates in the public consciousness the imagination and calls for respect for the values protected by the norms of IT law. The peculiarity is that within the

${ }^{11}$ Позова Д.Д. Система джерел правового регулювання інформаційно-технологічних відносин. Часопис ичивілістики. 2017. Вип. 24. С. 95. 
legal impact of IT law, values such as information, privacy, and selfidentification are objectified. that are not so obvious and do not come directly from human nature. The integration of values inherent in the information society into the existing system of legal values is a challenge facing IT law today.

The result of the psychological impact of law is the formation of an image of law in the totality of the elements that are included in it and the phenomena associated with it.

The formation of the individual's psychological attitude to law is influenced by the social group and society as a whole ${ }^{12}$. Within the limits of social reality, society is stratified on different grounds into groups without the need for individuals belonging to the social group to be even acquainted with one another. Political, economic, cultural processes in society create the conditions for the formation of a group endowed with a separate legal status (electorate, mass consumer, etc.).

Transformation of society by means of information technologies into a "reasonable society" implies the coexistence of both old (traditional) and new (non-traditional) forms of differentiation of society that determine the range of social expectations, requirements, services, and jobs.

Information technology development is a catalyst for stratification processes, with virtual communities emerging as a new form of social organization in the information space (forum and community members on social networks, newsletters, blog readers, etc.). The inevitable division of society into new "executions": users, creators of technology or personal options for using them ${ }^{13}$.

The indirect impact of IT law through group consciousness on the public consciousness also takes place.

The cultural direction of the influence of IT law is to increase the general cultural level of society through the harmonious introduction of the latest technologies in life, bringing the society to the achievements of modern civilization, using the latter to enhance the intellectual, ethical and spiritual levels of development of society as a whole.

At the behavioral level, law uses the power of its regulatory and protective influence to evaluate the actions of individuals by encouraging or condemning the latter. The specificity of IT law determines the following features of its impact on legal awareness at the behavioral level:

12 Шаравара I.I. Правосвідомість як юридична категорія та іiі основні структурні елементи. Науковий вісник Ужгородського національного університету: серія: Право. 2015. Вип. 33. Т. 1. С. 57.

${ }^{13}$ Інформаційні технології як фактор суспільних перетворень в Україні: зб. аналіт. доп. / М. А. Ожеван, С. Л. Гнатюк, Т. О. Ісакова; за заг. ред. Д. В. Дубова. К. : НІСД, 2011. С. 23. 
- given the progressive nature of the law, it is able to stimulate the relationship not only by ensuring their legal protection, but also can generate the latter in real life, "prompting" possible participants of the relationship the possible content of relations with the latest technologies;

- encourages the enhancement of process efficiency through the use of information technologies, while ensuring at the legislative level the freedom to use new communication opportunities and means.

Thus, law, on the one hand, is itself a formal manifestation of social consciousness, reflecting the perceptions and views of the various phenomena of reality formed in society. On the other hand, law influences the public consciousness, forming ideas and thoughts, ideas and values of society and prejudices the behavior of individuals.

Thus, IT law and public consciousness are interdependent, since IT law is the creation and reflection of public consciousness, while IT law influences further changes in public consciousness and the formation of legal culture in the field of information technology.

In the context of the study of the impact of IT law on the minds of individuals and the public consciousness, it is necessary to address the nature of IT relationships at the present stage and identify the place of IT law in the system of modern branches of law. In the context of the European integration of Ukraine and the subsequent recodification of civil law, the science of civil law must develop relevant approaches to determining the nature of IT relationships, taking into account the methods by which IT relationships should be regulated.

The scope of IT law regulation is extremely broad. When describing IT legislation, they often refer to the rules of civil, commercial and administrative law. Civil relations are especially distinguished in this area, because they are most relevant to the specifics of IT relations. IT relations that are governed by civil law generally include: contracts for the provision of software development or use services; civil contracts for work with IT specialists; contracts of legal support of freelancers; legal audit of IT companies; legal protection of web site owners and related content; registration and protection of copyright and trademark on the Internet; execution of the contract of sale of an individual IT object - site, domain, brand, etc. legal support of activity of online shops; creation and registration of legal entities in the field of information technology; license agreements; protection of intellectual property rights; protection of information, etc ${ }^{14}$.

${ }^{14}$ Харитонов Є.О. ІТ-право: альтернатива парадигми. Наукові праці Національного університету “Одеська юридична академія”. 2016. Т. 18. С. 19. 
The specificity of relations in the field of information technology is marked by the intensity of development of such relations, which causes complexity for the legislator in the matter of regulating such public relations. Thus, the lawmaking process should aim to form the most general rules and to overcome the gaps as soon as possible. At the same time, IT legislation should enable participants in these relationships to self-regulate their compliance with the general principles of the law ${ }^{15}$. In general, these statements are relevant to private-law relations, and therefore priority should be given to private-law methods in regulating information technology relations.

In support of the thesis on the priority of private-law methods in the regulation of relations in the field of information technology, it should also be noted separately that among the sources of regulation of relations in the field of IT include legal custom and a civil contract. Legal practices are usually understood to mean those rules of conduct that are not established by official legislative acts but are established in a particular field of relations. Thus, according to Art. 7 of the Civil Code of Ukraine, civil relations can be governed by custom, in particular, the custom of business turnover. The use of custom as a real regulator of relations in the field of IT relations is appropriate, because it is often the case that relations in the field of IT are derived from real civil relations and may be subject to the same customs of business turnover.

At the same time, considering the large number of loopholes in the regulation of IT relations and the widespread use of analogy of law and analogy of right in resolving disputes in the field of information technology, the construction of a civil contract generally corresponds to the specifics of the sphere of IT and will enable the participants of relations to freely carry out their rights to IT objects and enter into relations in the exercise of those rights. The legislator laid down this possibility in the content of Art. 6 of the Civil Code of Ukraine, according to which the parties have the right to enter into an agreement that is not provided for by the acts of civil law, but is consistent with the general principles of civil law (so-called "not named contracts"). In addition, it is provided that the parties may conclude one of the agreements envisaged by the civil law acts (the so-called "named contracts"), but to regulate in it their relations which are not at all regulated by these acts, or, if regulated, to depart from the provisions of civil law and to regulate them at their discretion. The only caveat to this is the inability to depart from the imperative provisions of civil law, namely: 1) unless explicitly stated in these acts; 2) if the obligation of the parties to the

15 Позова Д.Д. Система джерел правового регулювання інформаційно-технологічних відносин. Часопис ичивілістики. 2017. Вип. 24. С. 96. 
provisions of civil law acts derives from their content or from the substance of the relations between the parties ${ }^{16}$.

In addition, the literature has repeatedly demonstrated the need to enhance the use of private legal coercion in civil protective legal relationships ${ }^{17}$. Public and private coercion cannot be opposed but must complement each other, forming a system of methods for the protection of violated civil rights. The specifics of the methods of regulation of private legal relations require the widest possible application of private legal coercion in this field. The sphere of IT relations is already becoming a feature of the sphere of private legal relations, and therefore the use of private legal coercion corresponds to the specificity of the impact of IT law on public relations. Independent settlement of conflict situations, arise in violation of civil rights by entities in the field of information technology, maximizes the potential of the dispositive method of IT law. The use of self-defense, a pretentious form of influence over the offender are adequate ways of protecting one's own rights in the field of IT, their effectiveness and perspective are proven by daily practice.

\section{CONCLUSIONS}

The sphere of relations in the field of information technology is not homogeneous; it includes relations that are both public and private. Such relationships cannot be separated and co-existent in the field, and therefore the legal regulation of the field should take into account such specificity of relations in the field of IT. The areas of influence of IT law are not limited by the individual consciousness of participants in the relations in the field of IT, а й extend to the public consciousness, forming perceptions and behavioral stereotypes in society's consciousness. The dynamism and technology of the IT sphere determines the possibilities of regulating such public relations. The specifics of IT relationships require a broad involvement of a civil contract as a source of regulation of relations in the field of IT. In addition, a significant number of civil relations within the sphere of IT relations require the preferred use of private law methods in regulating this sphere of public relations. Shifting the Priority to Private Law Methods in the Regulation of Public Relations in the IT Sector is in line with current scientific approaches to determining the place of IT law in the law system.

\footnotetext{
${ }^{16}$ Позова Д.Д. Система джерел правового регулювання інформаційно-технологічних відносин. Часопис иивілістики. 2017. Вип. 24. С. 95.

${ }^{17}$ Яроцький В.Л. Приватно-правовий примус в цивільних охоронних правовідносинах. Вісник Національної академії правових наук України. 2018. № 1. С. 235.
} 


\section{SUMMARY}

Within the framework of the research, the perspectives of shifting the priority of methods of legal regulation of the sphere of IT relations in accordance with the vectors of influence of information technologies and IT law and the public consciousness are identified. In the context of the study it is proved that modern information technologies have caused the emergence and intensive dissemination of fundamentally new models of social integration, communication, sociopolitical activity, lifestyle, education and more. The problems of the topic are outlined, namely in the specifics of the sphere of information technologies the tendency of relations in this sphere to self-regulation is determined, which determines the perspective of the research.

It has been determined that law is a formal manifestation of public consciousness, reflecting the perceptions and views of the various phenomena of reality formed in society. On the other hand, law influences the public consciousness, forming ideas and thoughts, ideas and values of society and prejudices the behavior of individuals. IT law and the public consciousness are interdependent, since IT law is the creation and reflection of the public consciousness, while IT law influences further changes in the public consciousness and the formation of the legal culture in the field of information technology.

The specificity of modern relations in the field of information technologies and corresponding restrictions of legislative regulation of relations in the field of IT are determined. The idea of the composition of public relations related to the sphere of IT law has been formed. The utmost importance of civil contract and legal custom as sources of legal regulation of relations in the sphere of information technologies is proved. It has been determined that the design of a civil contract is broadly in line with the specifics of the IT field. The use of a civil contract in the regulation of relations in the field of IT will give the participants of the relationship the opportunity to exercise their rights freely over the objects of IT and enter into relations in the exercise of these rights.

The necessity of the widest possible use of private legal coercion in the protection of civil rights of participants of legal relations in the sphere of information technologies is proved. It has been found that self-management of conflicts arising from civil rights violations by information technology entities maximizes the potential of the dispositive method of IT law.

\section{REFERENCES}

1. Бурдоносова М.А. Правовий нігілізм як форма деформації правової свідомості населення. Держава і право. Вип. 45. С. 54-60.

2. Жарков Я. Небезпеки особистості в інформаційному просторі. Юридичний журнал. 2007. № 2. URL: http://www.justinian.com.ua/ article.php?id=2554 
3. Інформаційні технології як фактор суспільних перетворень в Україні: зб. аналіт. доп. / М. А. Ожеван, С. Л. Гнатюк, Т. О. Ісакова; за заг. ред. Д. В. Дубова. К. : НІСД, 2011. 96 с.

4. Колодюк А.В. Інформаційне суспільство: сучасний стан та перспективи розвитку в Україні: автореф. дис. на здобуття наук. ступеня канд. політ. наук. К., 2005. 20 с.

5. Новицький А.M. Місце IT-права в загальній системі інформаційного права. URL: http://aphd.ua/publication-179/

6. Позова Д.Д. Система джерел правового регулювання інформаційно-технологічних відносин. Часопис ичиілістики. 2017. Вип. 24. С. 93-96.

7. Скакун О.Ф. Теорія держави і права : підручник. Х. : Консум, 2001. $656 \mathrm{c}$.

8. Соснін О.В. Правова свідомість як фактор забезпечення засад захисту інформації. Захист інформаиії. 2010. № 1 (46). С. 9-14.

9. Стефанчук М. Приватноправовий метод регулювання суспільних відносин: стан та перспективи розвитку. Університетські наукові записки. 2005. № 4. С. 428.

10. Стефанчук У. Інформаційні технології та їхній вплив на формування громадської думки в Україні. Українська національна ідея: реалії та перспективи розвитку. 2008. Вип. 20 С. 129-133.

11. Харитонов С.О. IT-право: альтернатива парадигми. Наукові пращі Наиіонального університету “Одеська юридична академія”. 2016. Т. 18. C. 191-200.

12. Харитонов Є.О. Сутність IT-права (IT- право як концепт). IT право: проблеми і перспективи розвитку в Украӥні: збірник матеріалів науковопрактичної конференції. Львів: НУ “Львівська політехніка”, 2016. С. 274-280.

13. Шаравара I.I. Правосвідомість як юридична категорія та іï основні структурні елементи. Науковий вісник Ужсгородського національного університету: серія: Право. 2015. Вип. 33. Т. 1. С. 56-59.

14. Яроцький В.Л. Приватно-правовий примус в цивільних охоронних правовідносинах. Вісник Національної академії правових наук України. 2018. № 1. С. 219-236.

\section{Information about the author: Omelchuk O. S., Ph.D,} Associate Professor of Civil Law Department National University "Odesa Law Academy" Fontan road 23, Odesa, Ukraine ORCID ID: https://orcid.org/0000-0002-0082-3619 